\title{
Synthesis of chromones, annulated with oxygen-containing heterocycles with two hetero atoms at $\mathrm{C}(7)-\mathrm{C}(8)$ bond
}

\author{
Tetyana Shokol*, Natalia Gorbulenko, Volodymyr Khilya
}

Taras Shevchenko National University of Kyiv, Volodymyrska Street, 64/13, Kyiv 01601, Ukraine shokoltv@univ.kiev.ua

Keywords: annulation, chromones, 6H-[1,3]dioxolo[4,5-h]chromen-6-one, 2,3-dihydro-7H[1,4]dioxino[2,3-h]chromen-7-one, 3,4-dihydro-2H,8H-[1,4]dioxepino[2,3-h]chromen-8-one, 2,3dihydro-1H,7H-chromeno[7,8-b][1,4] oxazin-7-one, 4H,12H-pyrano[2,3-a]phenoxazine-4-one, 9,10-dihydro-4H,8H-chromeno[8,7-e][1,3]oxazin-4-one.

The present review represented the advanced synthetic strategies for chromones annulated at the $\mathrm{C}(7)-\mathrm{C}(8)$ bond with five-membered, six-membered, and seven-membered oxygen-containing heterocycles with two heteroatoms, such as $6 H$-[1,3]dioxolo[4,5- $h]$ chromen-6-one, 2,3-dihydro-7H[1,4]dioxino[2,3- $h]$ chromen-7-one, 3,4-dihydro-2H,8H-[1,4]dioxepino[2,3- $h]$ chromen-8-one, 2,3dihydro- $1 H, 7 H$-chromeno[7,8-b][1,4]oxazin-7-one, 4H,12H-pyrano[2,3-a]phenoxazine-4-one and 9,10-dihydro-4H,8H-chromeno[8,7-e][1,3]oxazin-4-one. The biological activity of naturally occurring and modified synthetic fused hetarenochromones has been also highlighted.

\section{Introduction}

Angular hetarenochromones are of considerable interest because of their abundance in natural flavonoids and some alkaloids and promising biological activity [1]. Chromones annulated with oxygencontaining cycle occupy a significant place among them. These are first and foremost furo[2,3- $h]$ chromones and pyrano[2,3$f$ chromones. Their syntheses and biological activity have been highlited in reviews [1, 2].
Chromone derivatives annulated with oxygencontaining ring with two heteroatoms, such as dioxolane and dioxane cycles, were also isolated from various natural sources. Their $\mathrm{O}, \mathrm{N}$-containing analogues remain unobserved among natural products. Chromones annulated with oxazole and oxazine cycles, namely 2-methylchromeno[7,8- $d][1,3]$ oxazol6-one, chromeno[7,8- $d][1,3]$ oxazol-2,6(3H)dione, $4 H$-chromeno[8,7-d][1,2]oxazol-4-one 
and 3,4-dihydrochromeno[8,7-b][1,4]oxazin$7(2 H)$-one are described in the review [1].

The present mini review is a continuation of the review [1] and is focused on the syntheses of chromones annulated at the $\mathrm{C}(7)$ $\mathrm{C}(8)$ bond with five-membered, sixmembered, and seven-membered oxygencontaining heterocycles with two heteroatoms, such as $6 H$-[1,3]dioxolo[4,5-h]chromen-6one, 2,3-dihydro-7H-[1,4]dioxino[2,3h]chromen-7-one, 3,4-dihydro- $2 \mathrm{H}, 8 \mathrm{H}$ [1,4]dioxepino[2,3- $h]$ chromen-8-one, $\quad 2,3-$ dihydro- $1 H, 7 H$-chromeno[7,8-b][1,4]oxazin7-one, 4H,12H-pyrano[2,3-a]phenoxazine-4one and 9,10-dihydro- $4 H, 8 H$-chromeno[8,7e][1,3]oxazin-4-one.

\section{Chromones, annulated with heterocycles containing two oxygen atoms}

This section is dedicated to the progress of chromones annulated with dioxolane, dioxane and dioxepane rings.

\section{1. $6 H$-[1,3]dioxolo[4,5-h]chromen-6-ones}

The system with an annulated dioxolane cycle to the chromone nucleus at the $\mathrm{C}(7)$ $\mathrm{C}(8)$ bond occurs in some natural flavonoids, such as granulosin 1a from the bark of Galipea granulosa [3, 4], bausplendin 2a from Bauhinia shlendens [5], maxima isoflavones A (3a) and D (3b) from aerial parts of Tephrosia maxima [6-8] and 7,8methylenedioxy-4'-methoxyisoflavone 4 from Indigofera linnaei [9] (Figure 1).<smiles>CCCc1cc(=O)c2ccc3c(c2o1)OCO3</smiles>

1a granulosin<smiles>[R]c1ccc(-c2coc3c4c(ccc3c2=O)OCO4)cc1[R]</smiles>

3a maxima isoflavone $\mathrm{A}$ $\mathrm{R}^{1}-\mathrm{R}^{2}=\mathrm{OCH}_{2} \mathrm{O}$

3b maxima isoflavone $D$ $\mathrm{R}^{1}=\mathrm{R}^{2}=\mathrm{OMe}$

$4 \mathrm{R}^{1}=\mathrm{OMe}, \mathrm{R}^{2}=\mathrm{H}$
Figure 1. Natural $6 H$-[1,3]dioxolo[4,5-h]chromen-6ones

Two strategies were applied for the construction of the $6 H$-[1,3]dioxolo[4,5$h$ ]chromen-6-one system: the formation of the dioxolane cycle on the basis of 7,8dihydroxychromones and the annulation of the $\gamma$-pyron ring to benzodioxole derivatives.

The first one was realized in the synthesis of bausplendin $\mathbf{2 a}$ and its analogues $\mathbf{2 b , c}$, which were synthesized from the corresponding 7,8-dihydroxyflavones by alkylation with diiodomethane [5], dibromomethane [10] or methylene sulfate [11] in DMSO [5], DMF [10] or acetone [11] in the presence of an inorganic base: $\mathrm{Na}_{2} \mathrm{CO}_{3}$ 
[5], $\mathrm{K}_{2} \mathrm{CO}_{3}[11]$ or $\mathrm{KF}$ [10] (Scheme 1).

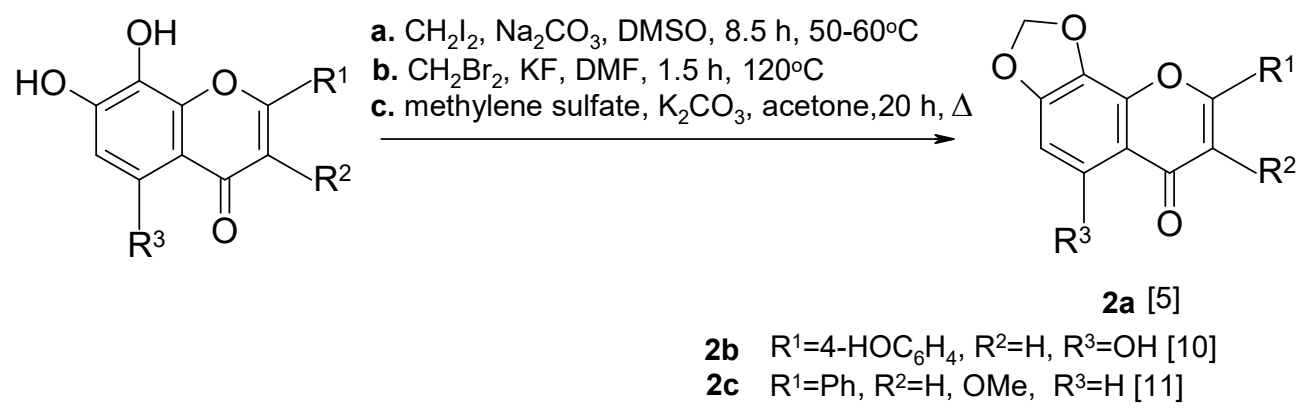

Scheme 1. The synthesis of bausplendin $\mathbf{2 a}$ and its analogues $\mathbf{2 b , c}$

7,8-Methylenedioxyisoflavones and their thiazole analogues of formula $\mathbf{5}$, were prepared via the alkylation of the corresponding 7,8-dihydroxychromones by diiodo $[12,13]$ and dibromomethane $[8,14$, $15]$ in the presence of $\mathrm{K}_{2} \mathrm{CO}_{3}$. When heated in acetone or dioxane, the reaction was completed in 36 [12] and 15 hours [8], respectively. When DMF $[8,14,15]$ or its mixture with acetone [13] has been used as a solvent, the reaction time was reduced to $1,5-$ $2 \mathrm{~h}$ and yield of target products was increased (Scheme 2).<smiles>[R]c1oc2c(O)c(O)ccc2c(=O)c1[14CH3]</smiles>

a. $\mathrm{CH}_{2} \mathrm{I}_{2}, \mathrm{~K}_{2} \mathrm{CO}_{3}$, acetone, $36 \mathrm{~h}, \Delta$ $[12,13]$, or

b. $\mathrm{CH}_{2} \mathrm{Br}_{2}, \mathrm{~K}_{2} \mathrm{CO}_{3}$, DMF, 1.5-2 $\mathrm{h}$ or dioxane, $15 \mathrm{~h}, 80-90^{\circ} \mathrm{C}$ $[8,14,15]$<smiles>[R]c1oc2c3c(ccc2c(=O)c1[Ga])OCO3</smiles>

5

$\mathrm{R}=\mathrm{H}, \mathrm{Me}, \mathrm{CF}_{3} ; \quad \mathrm{Het}(\mathrm{Ar})=\mathrm{Ph}, 4-\mathrm{FC}_{6} \mathrm{H}_{4}, 4-\mathrm{ClC}_{6} \mathrm{H}_{4}, 4-\mathrm{MeOC}_{6} \mathrm{H}_{4}, 3,4-(\mathrm{MeO})_{2} \mathrm{C}_{6} \mathrm{H}_{3}$,<smiles>Cc1ccc2c(c1)OCCO2</smiles>

Scheme 2. The synthesis of 7,8-methylenedioxyisoflavones and their thiazole analogues $\mathbf{5}$

Alkylation of the natural chromone retusin 6, with $\alpha$-dichlorodiphenylmethane upon heating in an oil bath to $210^{\circ} \mathrm{C}$ until the evolution of HCI gas ceased (5 min) resulted in the diphenylmethylene derivative 7 [16] (Scheme 3). 

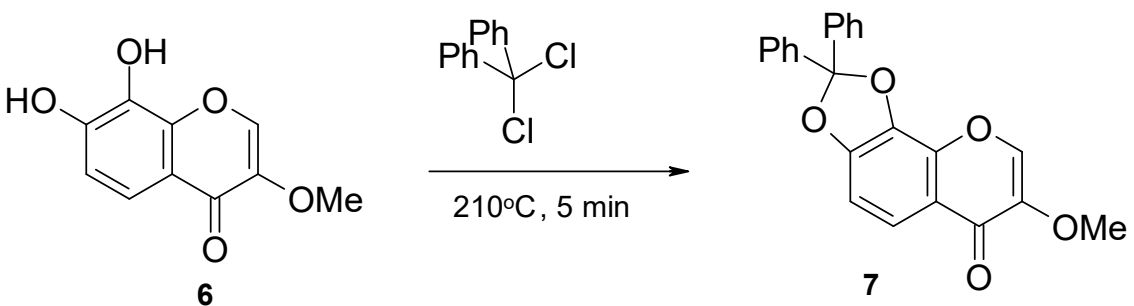

Scheme 3. Alkylation of the natural chromone retusin 6 with $\alpha$-dichlorodiphenylmethane

Granulosin 1a and its analogues 1b-e, all of which exhibit toxicity to the brine shrimp Artemia salina, have been prepared from 2',3',4'-trihydroxyacetophenone using a second approach. The first step of the synthesis involved the formation of the benzodioxole derivative $\mathbf{8}$ via the regioselective acetalisation of $2^{\prime}, 3^{\prime}, 4^{\prime}-$ trihydroxyacetophenone (Scheme 4) using 1 equivalent of bromochloromethane in the presence of cesium carbonate. Treatment of 2'-hydroxy-3',4'-methylendioxy)acetophenone 8 with two equivalents of sodium ethoxide in ethanol afforded the enolate which, on reaction with a series of ethyl carboxylate esters gave mixtures of the corresponding enols 9 and their cyclic derivatives 10, according to NMR spectroscopy. Treatment of these mixtures with a mixture of acetic and sulfuric acids $\quad$ afforded methylenedioxychromones 1a-e in $58-85 \%$ yields [4].<smiles>CC(=O)c1ccc(O)c(O)c1O</smiles>

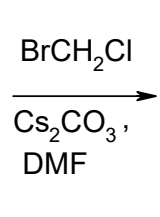<smiles>CC(=O)c1ccc2c(c1O)OCO2</smiles><smiles>[R]OC(=O)OCC</smiles><smiles>[R]/C(O)=C/C(=O)c1ccc2c(c1O)OCO2</smiles><smiles></smiles>

8<smiles>[R]C1(O)CC(=O)c2ccc3c(c2O1)OCO3</smiles>
1a-e $\mathrm{R}=\operatorname{Pr}(\mathbf{a}), \mathrm{Me}(\mathbf{b}), \mathrm{Et}(\mathbf{c}), \mathrm{i}-\operatorname{Pr}(\mathbf{d}), \mathrm{PhCH}_{2}(\mathbf{e})$

Scheme 4. The synthesis of Granulosin 1a and its analogues 1b-e

Cyclization of chalcones 11, obtained from acetophenone $\mathbf{8}$ and benzaldehydes, in TFA resulted in 7,8-methylenedioxyflavanones $\mathbf{1 2}$, which on oxidation with $\mathrm{I}_{2}$ in DMSO gave 7,8-methylenedioxyflavones $\mathbf{1 3}[9,17,18]$ (Scheme 5). Finally, the flavone 13b was also prepared in $95 \%$ yield by simply heating chalcone 11b under reflux in DMSO 
containing a crystal of $\mathrm{I}_{2}[9]$.

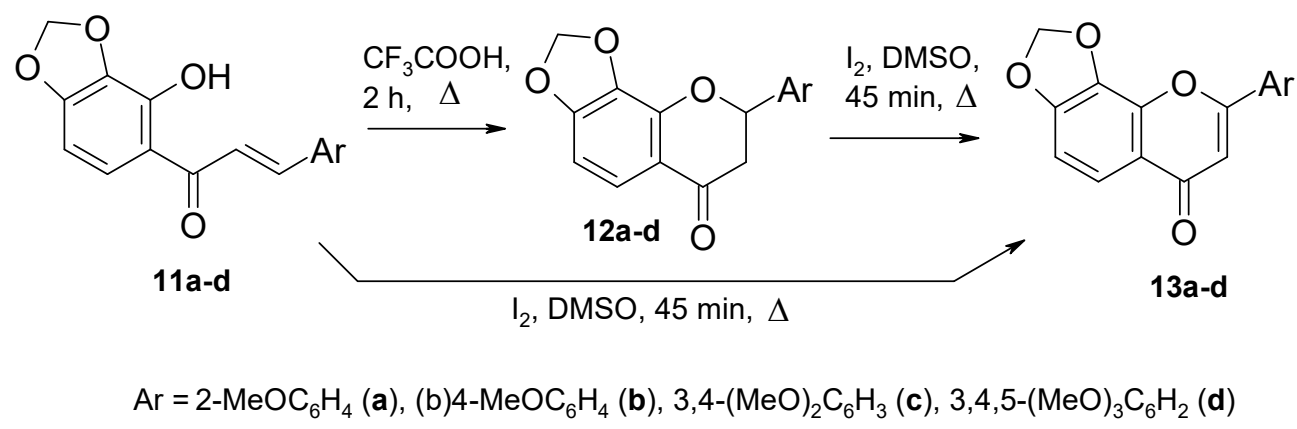

Scheme 5. Oxidative cyclization of chalcones 11

This new series of chalcones 11, readily available plant metabolite from dill flavanones 12 and flavones 13 have been assessed for their effect on proliferation, and parsley seeds [19] (Scheme 6). The cytotoxic potential and apoptosis in human reaction sequence involved an efficient leukemia cells. Among the tested compounds, conversion of the key intermediate epoxide $\mathbf{1 6}$ the chalcone series showed the best activity and chalcone 11a showed a significant effect on down-regulation of cancer cell proliferation and viability in three different leukemia cell lines (K562, Jurkat, U937) [17].

A mixture of 7,8into the respective $\beta$-ketoaldehyde $\mathbf{1 7}$ followed by its $\mathrm{Cu}(\mathrm{I})$-mediated cyclization into the target 7,8-methylenedioxyisoflavone 14 and its 5-unsubstituted derivative 15, obtained due to the instability of the 5-OMe group under experimental conditions (overall yield 22\%). The latter compound 15 was methylenedioxyisoflavones $\mathbf{1 4}$ and 15 (13:10 ratio, respectively) was obtained starting with successfully isolated from the reaction mixture via chromatography.<smiles>C=CCc1cc2c(c(OC)c1OC)OCO2</smiles><smiles>COc1ccc(C(C=O)C(=O)c2c(Br)c3c(c(OC)c2OC)OCO3)c(OC)c1OC</smiles> 


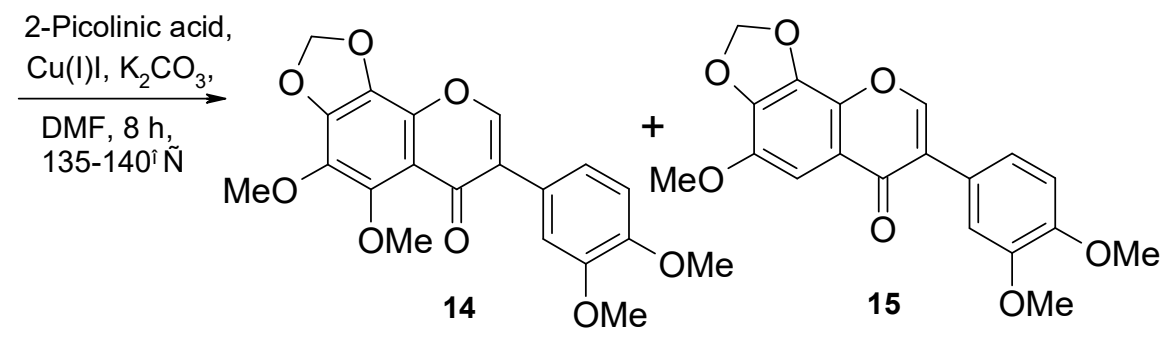

Scheme 6. The synthesis of 7,8-methylenedioxyisoflavones $\mathbf{1 4}$ and $\mathbf{1 5}$ from epoxides $\mathbf{1 6}$

7,8-Methylenedioxyisoflavones and their homoanalogs can also be obtained via formylation of deoxybenzoines and their homo-analogs followed by the $\gamma$-pyron ring closure, as shown in Scheme 7. Thus, 4-(6oxo-6H-[1,3]dioxolo[4,5- $h]$ chromen-7-

yl)benzoic acid 18, patented as useful for treating vascular diseases, was obtained from deoxybenzoine 19 upon treatment with DMF and borontrifluoride-diethyletherate, followed by methanesulfonylchloride addition and heating at $90^{\circ}-100^{\circ}$ for $2 \mathrm{~h}$ [20]. 2'-Hydroxydihydrochalcone $\mathbf{2 0}$ was subjected to cyclization by treatment with N,Ndimethylformamide diethyl acetal to give homoisoflavone 21, which on reduction and deracemization resulted in homoisoflavonone, isolated from Chlorophytum Inornatum [21].<smiles>CCOC(C)C(C)C(C)OCC</smiles><smiles>O=C(O)c1ccc(-c2coc3c4c(ccc3c2=O)OCO4)cc1</smiles><smiles>CCOC(OCC)N(C)CC[C@H](Cc1ccc(OC)cc1)Oc1ccc2c(c1OC)OCO2</smiles>

Scheme 7. The synthesis of 7,8-methylenedioxyisoflavones and their homoanalogs via formylation of deoxybenzoines and their homo-analogs 
Synthesis of 5-hydroxy-2-methyl-7,8methylenedioxy-4'-methoxyisoflavone 22 by the first approach and its conversion to 5- methoxy-7,8-methylenedioxy-4'-

methoxyisoflavone $\mathbf{2 3}$ using the second strategy is reported in [22] (Scheme 8).<smiles>Cc1oc2c(O)c(O)cc(O)c2c(=O)c1Br</smiles>

methylene sulfate

$\mathrm{KOH}, \mathrm{EtOH}, \mathrm{H}_{2} \mathrm{O}$, $45-50^{\circ} \mathrm{C}, \mathrm{N}_{2}$ atm.<smiles>Cc1oc2c3c(cc(O)c2c(=O)c1Br)OCO3</smiles>
$\mathrm{Me}_{2} \mathrm{SO}_{4}$ $\mathrm{K}_{2} \mathrm{CO}_{3}$ $\mathrm{Ar}=4-\mathrm{MeOC}_{6} \mathrm{H}_{4}$ 22<smiles>COc1cc2c(c3oc(C)c(C(=O)O)c(=O)c13)OCO2</smiles><smiles>COc1cc2c(c(O)c1C(=O)C[Al])OCO2</smiles>
$\mathrm{HCO}_{2} \mathrm{Et}$ $\mathrm{Na}-10^{\circ} \mathrm{C}$ 3 days<smiles>COc1cc2c(c3occ(Br)c(=O)c13)OCO2</smiles>

Scheme 8. The synthesis of 7,8-methylenedioxyisoflavones 22 and $\mathbf{2 3}$

\subsection{2,3-Dihydro-7H-[1,4]dioxino[2,3-}

\section{h]chromen-7-ones}

Annulation of the 1,4-dioxane heterocycle to the chromone system at $\mathrm{C}(7)-\mathrm{C}(8)$ bond leads to the formation of 2,3-dihydro- $7 \mathrm{H}$ $[1,4]$ dioxino[2,3- $h]$ chromen-7-ones.
This system is the basis of the molecules of scutellasprostins A, B, C 24a-c [23] and xanthocercines A and B 25a,b [24] flavolignans isolated from the plants Scutellaria prostrata and Xanthocercis zambesia, respectively (Figure 2).

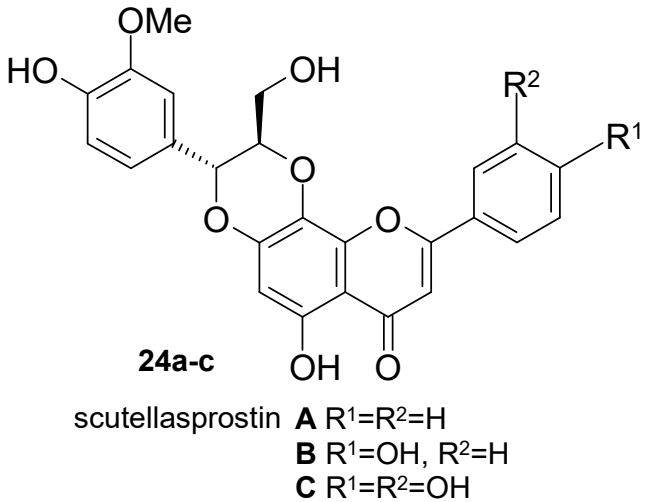<smiles>[R]c1cc([C@@H]2Oc3ccc4c(=O)c(-c5ccc(OC)c(O)c5)coc4c3O[C@H]2CO)cc(OC)c1O</smiles>

Figure 2. Natural 2,3-dihydro-7H-[1,4]dioxino[2,3-h]chromen-7-ones 
Synthesis of these compounds and their isoflavones in the presence of silver oxide analogues was realized by oxidative coupling of the coniferyl or synapic alcohol with the [23-25] or horsradish peroxidase [26] corresponding natural flavones and

\section{(Scheme 9).}<smiles>COc1cc(/C=C/CO)ccc1O</smiles><smiles>[R]c1ccc(-c2cc(=O)c3c([R])cc(O)c(O)c3o2)cc1[R]</smiles><smiles>[R]c1ccc(-c2cc(=O)c3c([R])cc4c(c3o2)OCCCO4)cc1</smiles><smiles>[R]c1cc(/C=C/CO)cc(OC)c1O</smiles>

$\mathrm{R}^{1}=\mathrm{R}^{2}=\mathrm{H} ; \mathrm{R}^{1}=\mathrm{OH}, \mathrm{R}^{2}=\mathrm{H} ; \mathrm{R}^{1}=\mathrm{R}^{2}=\mathrm{OH}$<smiles></smiles>

Scheme 9. The synthesis of natural 2,3-dihydro-7H-[1,4]dioxino[2,3- $h]$ chromen-7-ones

Synthetic analogues of xanthocercin with unsubstituted dioxane ring 26, were prepared from 7,8-dihydroxyisoflavones and their 3- hetaryl analogues via the alkylation with 1,2dibromoethane in dioxane or DMF in the presence of $\mathrm{K}_{2} \mathrm{CO}_{3}[8,14,15]$ (Scheme 10).<smiles>[R]c1oc2c(O)c(O)ccc2c(=O)c1[GeH3]</smiles>

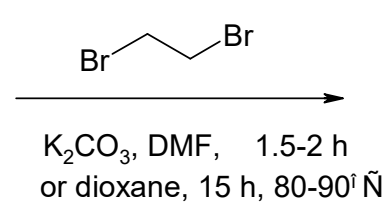

$\mathrm{R}=\mathrm{H}, \mathrm{Me}, \mathrm{CF}_{3} ; \operatorname{Het}(\mathrm{Ar})=\mathrm{Ph}, 4-\mathrm{FC}_{6} \mathrm{H}_{4}, 4-\mathrm{ClC}_{6} \mathrm{H}_{4}$,<smiles>[R]c1oc2c3c(ccc2c(=O)c1[13CH])OCCO3</smiles>

26<smiles>Cc1ccc2c(c1)OCCO2</smiles>

Scheme 10. The synthesis of 2,3-dihydro-7H-[1,4]dioxino[2,3-h]chromen-7-ones via the alkylation of 7,8dihydroxychromones with 1,2-dibromoethane

Upon alkylation of 7,8-dihydroxyflavone with 2-chloromethyloxirane 3-hydroxymethyl-
2,3-dihydro-7H-[1,4]dioxino[2,3-h]chromen-

7-one 27 [27] was obtained, while the reaction 
with ethyl 2,3-dibromopropanoate resulted in a mixture of the regio isomers $\mathbf{2 8}$ and $\mathbf{2 9}$, which was separated by fractional crystallisation. Selective group transformation in compound 29 using various ethylenediamine derivatives is furnished in a series of amides 30a-f in 40-73\% yields [28] (Scheme 11). In the spasmolysis test, 30b showed significant antagonistic effect towards the acetylcholine agonists, barium chloride and histamine [28].<smiles>O=c1cc(-c2ccccc2)oc2c(O)c(O)ccc12</smiles><smiles>O=c1cc(-c2ccccc2)oc2c(O)c(O)ccc12</smiles><smiles>[R]N([R])CCNC(=O)C1COc2c(ccc3c(=O)cc(P)oc23)O1</smiles>

$\mathrm{R}^{1}=\mathrm{R}^{2}=\mathrm{H}(\mathbf{a}), \mathrm{Me}(\mathbf{b}), \mathrm{Et}(\mathbf{c}) ; \mathrm{R}^{1}=\mathrm{H}, \mathrm{R}^{2}=\mathrm{Me}$

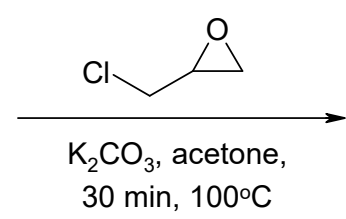<smiles>[R]OC(=O)OC(C)(C)C(=O)OCC</smiles><smiles>[R]O[R10](=O)c1ccccc1</smiles>

(d), Et (e), i-Pr (f)<smiles>O=c1cc(-c2ccccc2)oc2c3c(ccc12)OC(CO)CO3</smiles>

27<smiles>CCOC(=O)C1COc2ccc3c(=O)cc(-c4ccccc4)oc3c2O1</smiles>

$288 \%$<smiles>CCOC(=O)C1COc2c(ccc3c(=O)cc(-c4ccccc4)oc23)O1</smiles>

Scheme 11. The synthesis of 2,3-dihydro-7H-[1,4]dioxino[2,3- $h]$ chromen-7-ones with substituted dioxine ring

An alternative way to the 2,3-dihydro- $7 \mathrm{H}$ $[1,4]$ dioxino $[2,3-h]$ chromene-7-one system is the construction of $\gamma$-pyron ring based on benzodioxane derivatives.

Acetylation of 5-hydroxy-6acetylbenzodioxane $\mathbf{3 1}$ with (het)aroyl chlorides followed by rearrangement into $\beta$ diketones 32 and their cyclization in an acidic medium produced 9-(het)aryl-2,3-dihydro-7H$[1,4]$ dioxino[ $[2.3-h]$ chromen-7-ones 33 , which were tested for the ability to activate the cystic fibrosis transmembrane conductance regulator 
(CFTR) of both wild type CFTR and a mutant in some human subjects [29] (Scheme 12).

CFTR (G551D-CFTR) that causes cystic fibrosis<smiles>CC(=O)c1ccc2c(c1O)OCCO2</smiles><smiles></smiles><smiles>[R]C(=O)Oc1c(C(C)=O)ccc2c1OCCO2</smiles><smiles>[R]C(=O)CC(=O)c1ccc2c(c1O)OCCO2</smiles><smiles>[R]c1cc(=O)c2ccc3c(c2o1)OCCO3</smiles>

$\mathrm{R}=\mathrm{Ph}, 2-\mathrm{FC}_{6} \mathrm{H}_{4}, 4-\mathrm{MeOC}_{6} \mathrm{H}_{4}, 4-\mathrm{FC}_{6} \mathrm{H}_{4}, 3-\mathrm{FC}_{6} \mathrm{H}_{4}, 4-\mathrm{IC}_{6} \mathrm{H}_{4}$, pyridin-4-yl

Scheme 12. The synthesis of 2,3-dihydro-7H-[1,4]dioxino[2,3- $h]$ chromen-7-ones starting from 5-hydroxy-6acetylbenzodioxane

Condensation of 3-hydroxymethyl-5- derivative 34, which was further modified by hydroxy-6-acetylbenzodioxane with N,N- the hydroxyl group into compounds 35, dimethylformamide dimethylacetal and patented as useful for the treatment of subsequent cyclization in the presence of depressive disorders [30,31] (Scheme 13). sulfuric acid results in 2-hydroxymethyl<smiles>CCC1=CCNCC1</smiles>

Scheme 13. The synthesis of 2,3-dihydro-7H-[1,4]dioxino[2,3- $h]$ chromen-7-ones starting from 3-hydroxymethyl5-hydroxy-6-acetylbenzodioxane 


\subsection{3,4-Dihydro-2H,8H-[1,4]dioxepino[2,3-}

\section{$h$ ]chromen-8-ones}

Annulation of dioxepane cycle to chromone system was carried out using the same starting 7,8-dihydroxychromones, on the basis of which chromones condensed with dioxolane and dioxane cycles were synthesized.

Thus, upon the alkylation of 7,8dihydroxyisoflavones and their analogues with benzodioxane, benzodioxepane and thiazole substituents with 1,3dibromopropane in DMF (1,5-2 h) or dioxane $(22 \mathrm{~h})$, products of the dioxepane cycle annulation to the chromone nucleus, namely 3,4-dihydro- $2 H, 8 H$-[1,4]dioxepino[2,3$h]$ chromen-8-ones 36 were formed $[8,14,15]$ (Scheme 14).<smiles>[R]c1oc2c(O)c(O)ccc2c(=O)c1[GeH3]</smiles>

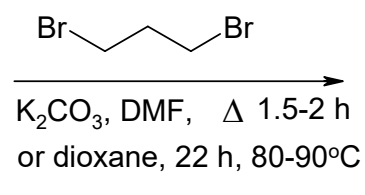

$\mathrm{R}=\mathrm{H}, \mathrm{Me}, \mathrm{CF}_{3} ; \quad \mathrm{Het}(\mathrm{Ar})=\mathrm{Ph}, 4-\mathrm{FC}_{6} \mathrm{H}_{4}, 4-\mathrm{ClC}_{6} \mathrm{H}_{4}$,<smiles>Cc1ccc2c(c1)OCCO2</smiles>

Scheme 14. The synthesis of 3,4-dihydro- $2 H, 8 H$-[1,4]dioxepino[2,3- $h]$ chromen-8-ones

\section{Chromones, annulated with}

\section{(benz)oxazine cycles}

2,3-Dihydro- $1 H, 7 H$-chromeno[7,8-

$b][1,4]$ oxazine-7-one is an azaanalogue of 2,3-dihydro-7H-[1,4]dioxino[2,3- $h]$ chromene- 7-one. 8-Nitro-7-(2-oxopropoxy)chromone 37 has been selectively reduced to the amine, which spontaneously cyclizes into 2-methyl2,3-dihydro- $1 H, 7 H$-chromeno[7,8b] [1,4] oxazin-7-one 38 [32] (Scheme 15). 
<smiles>CCOC(=O)C1CC(=O)c2ccc(OCC(C)=O)c([N+](=O)[O-])c2O1</smiles>

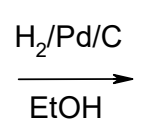<smiles>CCOC(=O)c1cc(=O)c2ccc3c(c2o1)NC(C)CO3</smiles>

Scheme 15. The synthesis of 2-methyl-2,3-dihydro-1H,7H-chromeno[7,8-b][1,4] oxazin-7-one 38

Its 2-oxo analogue 39 was obtained upon cyclization of 7-hydroxy-8chloroacetylaminochromone $\mathbf{4 0}$ in the presence of AcOK [32] (Scheme 16). 2,3Dihydro- $1 H, 7 H$-chromeno[7,8-b][1,4]oxazin- 2,7-diones 41, synthesized on the basis of 7hydroxy-8-aminochromones 42 and pulvinic acid dilactone, were tested for antimicrobial activity [33] (Scheme 16).<smiles>CCOC(=O)c1cc(=O)c2ccc(O)c(NC(=O)CCl)c2o1</smiles>

40<smiles>CCOC(=O)c1cc(=O)c2ccc3c(c2o1)NC(=O)CO3</smiles>

39<smiles>[R]c1c(C)oc2c(N)c(O)ccc2c1=O</smiles>

42<smiles>O=C1OC2=C(c3ccccc3)C(=O)OC2=C1c1ccccc1</smiles>
or $12 \mathrm{~h}$, room. $\mathrm{t}$.

$\mathrm{R}=\mathrm{H}, \mathrm{Me}$<smiles>[R]c1c(C)oc2c3c(ccc2c1=O)OC(c1ccccc1)(C1OC(=O)C(O)=C1O)C(=O)N3</smiles>

41

Scheme 16. The synthesis of 2,3-dihydro- $1 H, 7 H$-chromeno[7,8-b][1,4]oxazin-2,7-diones 39 and 41

The interaction of 7-hydroxy-8aminochromone 42 with a number of orthonitrochlorobenzenes resulted in annulation of the benzoxazine ring to the chromone nucleus and formation of 4H,12H-pyrano[2,3a]phenoxazine-4-ones 43 [34] (Scheme 17) . 
<smiles>Cc1cc(=O)c2ccc(O)c(N)c2o1</smiles>

42<smiles>[R]c1c([R])c([R])c2c(c1[R])Nc1c(ccc3c(=O)cc(C)oc13)O2</smiles>

43

Scheme 17. The synthesis of 4H,12H-pyrano[2,3-a]phenoxazine-4-ones 43

Upon the interaction of 7- one nucleus took place leading to the hydroxychromones 44 with amines and the annulation of the 3,4-dihydro-1,3-oxazine ring excess (2 equiv.) of formalin under the to the chromone core and the formation of Mannich reaction conditions simultaneous $C$ 9,10-dihydro-4H,8H-chromeno[8,7and $O$-aminomethylation of the benzopyran-4e][1,3]oxazin-4-ones 45 [35-41] (Scheme 18).<smiles>[R]c1cc2c(=O)c([R4])c([R])oc2cc1O</smiles>

$\mathrm{R}^{1}=\mathrm{H}, \mathrm{Me}, \mathrm{CF}_{3} ; \mathrm{R}^{3}=\mathrm{H}, \mathrm{Me}, \mathrm{Et}, \mathrm{Pr}$;

$\mathrm{R}^{2}=\mathrm{Ph}, 2-\mathrm{FC}_{6} \mathrm{H}_{4}, 2-\mathrm{MeOC}_{6} \mathrm{H}_{4}, 4-\mathrm{MeOC}_{6} \mathrm{H}_{4}, 3,4-(\mathrm{MeO})_{2} \mathrm{C}_{6} \mathrm{H}_{3}$,<smiles>COC(=O)c1cc(C)c(C)o1</smiles>

$\mathrm{R}=\mathrm{Pr}, \mathrm{i}-\mathrm{Pr}, \mathrm{MeO}\left(\mathrm{CH}_{2}\right)_{3}, \mathrm{MeO}\left(\mathrm{CH}_{2}\right)_{2}, 2-\mathrm{MeOC}_{6} \mathrm{H}_{4}\left(\mathrm{CH}_{2}\right)_{2}, \mathrm{Ph}\left(\mathrm{CH}_{2}\right)_{3}$,

cyclopropyl, sulfolan-3-yl, pycolyl-4, 4- $\mathrm{MeOC}_{6} \mathrm{H}_{4}$,<smiles>CN1CCOCC1</smiles>

$\mathrm{n}=1,2 ; \quad \mathrm{X}=\mathrm{O}, \mathrm{S}$<smiles>CCC1CCCN2CCCC[C@H]12</smiles>

$\mathrm{CH}_{2} \mathrm{COOH},\left(\mathrm{CH}_{2}\right)_{2} \mathrm{COOH}, \mathrm{CH}$ (Alk) $\mathrm{CO}_{2} \mathrm{Me}$

Alk=Me, $\mathrm{CHMe}_{2}, \mathrm{CH}_{2} \mathrm{CHMe}_{2}, \mathrm{CH}_{2} \mathrm{Ph}, \mathrm{CH}(\mathrm{Me}) \mathrm{Et}$

Scheme 18. The synthesis of 9,10-dihydro- $4 H, 8 H$-chromeno[8,7-e][1,3]oxazin-4-ones 45 
As a substrate, natural flavones [35], isoflavones [36, 37], their synthetic analogues [37-39] and 3-hetaryl derivatives [40] were used. Primary aliphatic [36, 37], aromatic [36], heterocyclic amines [35], amino acids [40] and their esters [39], amino alcohols [41] and alkaloids [38] served as an amine component.

For the first time, the $\mathbf{4 5}$ system was obtained in 31\% yield from 7-hydroxyflavone and 2-amino-4-phenylthiazole, when boiling in acetic acid with an excess of $40 \%$ formalin and paraform followed by ammonia treatment, after removal of the solvent [35].

The reaction of isoflavones with amines was carried out by refluxing in propanol-2 in the presence of a catalytic amount of N,Ndimethylaminopyridine (DMAP). With aliphatic amines, as well as benzyl- or hetarylalkylamines and alkaloid lupine derivative, $\quad 9,10$-dihydro- $4 H, 8 H$ chromeno[8,7-e][1,3]oxazin-4-ones $\mathbf{4 5}$ are formed in $65-84 \%$ yields. In the case of aromatic amines, $p$-methoxyaniline formed the product $\mathbf{4 5}$ in a satisfactory yield, while the reaction with $o$-substituted anilines have not resulted in the desired polycyclic system [36].

The reaction with amino acids and their esters was carried out in aqueousalcoholic solution without a catalyst with the excess (2 equiv.) of amino acid. While the interaction of isoflavones with amino acid esters runs smoothly and derivatives 45 [39] form in high yields, the reaction products of 7-hydroxy-3-hetarylchromones and amino acids depend on the type of heterocycle and amino acid [40]. 9,10-Dihydro-4H,8Hchromeno[8,7-e][1,3]oxazin-4-ones 45 were synthesized from glycine and 3azolylchromones, $\quad$ except 3 isoxazolylchromone [40]. In this case, the Mannich base $\mathbf{4 6}$ was isolated (Figure 3). The reaction with $\beta$-alanine is similar to the reaction with glycine, while proline did not participate in the reaction and bis(6-ethyl-3hetaryl-7-hydroxychromon-8-yl)methanes $\mathbf{4 7}$ were isolated 47 [40] (Figure 3).

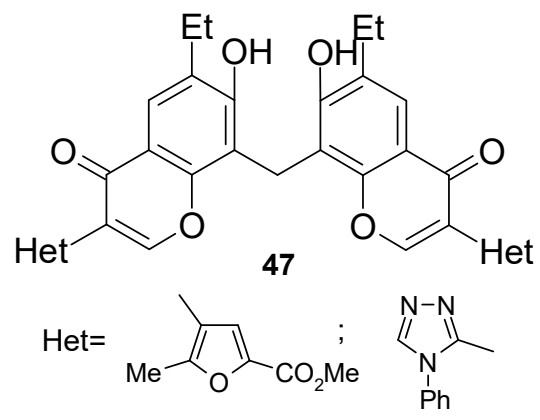

Figure 3. Structures of Mannich reaction products 46 and 47 
In the case of 3-azinylchromones, (3pyridyl- and 3-quinolylchromones) complex mixtures of unidentifiable products were obtained [40].

An attempt of receiving a linear system isomeric to $\mathbf{4 5}$ from 8-substituted-7hydroxychromones and glycine under above mentioned conditions [40] failed.

The aminomethylation of 7hydroxyisoflavones with 2-aminoethanol, 3amino-1-propanol, 4-amino-1-butanol and 5amino-1-pentanol in the presence of excess formaldehyde led principally to 9-(2-<smiles>[R]c1ccc(-c2c([R])oc3c4c(ccc3c2=O)OCN(CC)C4)cc1[R]</smiles>

45

$\mathrm{R}^{1}=\mathrm{H}, \mathrm{Me}, \mathrm{CF}_{3} ; \mathrm{R}^{2}=\mathrm{F}, \mathrm{OMe} ; \mathrm{R}^{3}=\mathrm{H}, \mathrm{OMe}$

(a) $\mathrm{HOCH}_{2}\left(\mathrm{CH}_{2}\right)_{\mathrm{n}} \mathrm{NH}_{2}$, where $\mathrm{n}=1-4, \mathrm{CH}_{2} \mathrm{O}$, EtOH or $i$-PrOH, DMAP, $80^{\circ} \mathrm{C}, 4-6 \mathrm{~h}$;

(b) bis(1,3-oxazolidin-3-yl)methan, dioxane, $100{ }^{\circ} \mathrm{C}, 2-4 \mathrm{~h}$;

(c) 3-butoxymethyl-1,3-oxazolidin, dioxane, $100^{\circ} \mathrm{C}, 2-4 \mathrm{~h}$.

Scheme 19. Aminomethylation of 7-hydroxyisoflavones with aminoalcohols

6-Hydroxymethyl-9,10-dihydro- $4 H, 8 H$ -

chromeno[8,7-e][1,3]oxazin-4-ones

49

(Figure 4), synthesized from natural flavone chrysin, fluoroanilines and an excess (12 equiv.) of formalin in $\mathrm{MeOH}$ were patented as useful in treating hyperuricemia [42] (Figure 4).<smiles>[R2]c1ccc(-c2c([R])oc3c(CN4CCCCC4)c(O)ccc3c2=O)cc1[R]</smiles>

hydroalkyl)-9,10-dihydro-4H,8H-

chromeno[8,7-e][1,3]-oxazin-4-ones

and/or the tautomeric 7-hydroxy-8-(1,3oxazepan-3-ylmethyl)-4H-chromen-4-ones $\mathbf{4 8}$ [41] (Scheme 19). The ratio of these tautomers was dependent on solvent polarity, electronic effects of aryl substituents in the isoflavone and the structure of the amino alcohol. NMR studies confirmed the interconversion of tautomeric forms. 
In recent years, with the rapid development of biobased materials, using renewable phenolic or amine derivatives to replace the petroleum-based raw materials for the synthesis of benzoxazine monomers has attracted considerable attention. A biobased benzoxazine resin (Dz-f) demonstrating excellent thermal properties was synthesized from daidzein, paraformaldehide and furfurylamine by using a microwave-assisted heating method in DMSO or PEG 400 as a solvent.[43]. The benzoxazine monomer $\mathbf{5 0}$ synthesis is shown in Scheme 20.

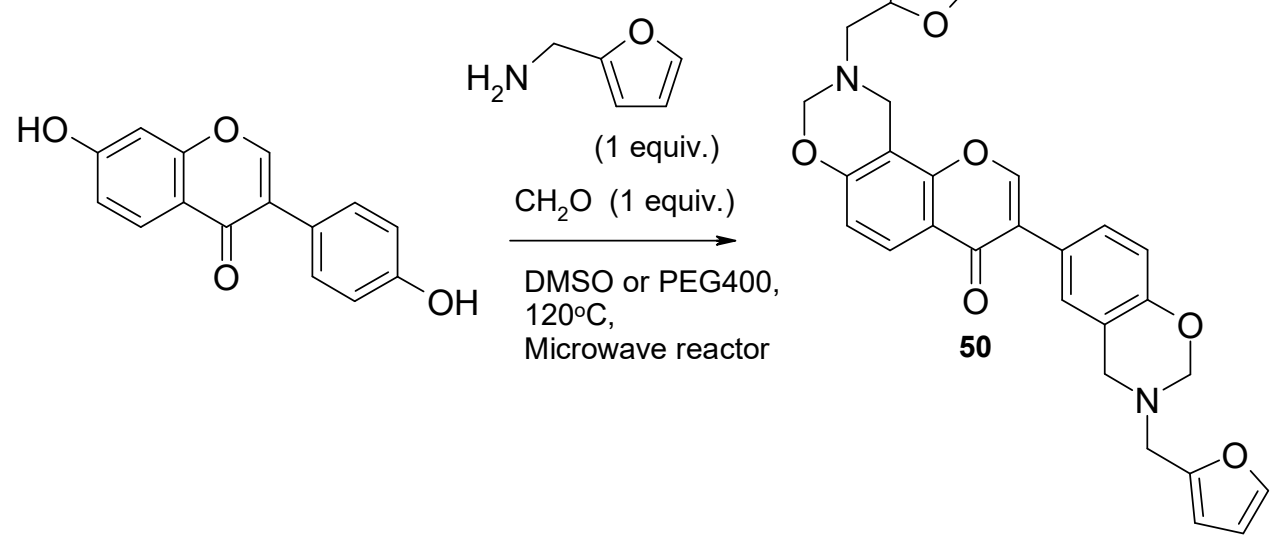

Scheme 20. The synthesis of the biobased benzoxazine resin (Dz-f) monomer $\mathbf{5 0}$

\section{Conclusions}

Further search for natural substances and creating new ones among angular hetarenochomones as well as development of

\section{References}

[1] Lozinski OA, Shokol TV, Khilya VP. Synthesis and biological activity of chromones annelated at the $\mathrm{C}(7)-\mathrm{C}(8)$ bond with heterocycles. Chem. Heterocycl. Comp. 2011; 47(9): 1055-1077.

[2] Shokol T, Lozinski O, Gorbulenko $\mathrm{N}$, Khilya $\mathrm{V}$. The synthesis of angular the new methods of their syntheses opens up broad prospects in order to create new highly effective materials for medicine and agriculture.

hetarenochromones based on 7-hydroxy-8carbonylchromones. Fr.-Ukr. J. Chem. 2017; 5(2): 6894.

[3] Lopez JA, Barillas W, GomesLaurito J, Martin GE, Al-Rehaily AJ, Zemaitis MA, Schiff PLJr. Granulosin, a new chromone from Galipea granulosa. J. Nat. Prod. 1997; 60(1): 24-26. 
[4] Kaye PT, Nchinda AT, Gray CA. Chromone studies. Part 11. Synthesis and electronimpact mass spectrometric study of granulosin and side-chain analogues. J. Chem. Res. (S). 2002; (7): 321-325

[5] Laux DO, Stefani GM, Gottlieb OR. Bausplendin, a dimethylenedioxyflavone from Bauhinia splendens. Phytochemistry 1985; 24(5): 1081-1084.

[6] Touqeer S, Saeed MA, Ajaib M. A Review on the Phytochemistry and Pharmacology of Genus Tephrosia. Phytopharmacology 2013; 4(3): 598637.

[7] Venkata Rao E, Sree Rama Murty M, Ward RS. Nine isoflavones from Tephrosia maxima. Phytochemistry 1984; 23(7): 1493-1501.

[8] Aitmambetov A, Khilya VP. Synthetic and modified isoflavonoids. XI. Synthesis of analogues of maxima isoflavone $\mathrm{A}$ and xanthocercin. Chem. Nat. Comp. 1994; 30(3): 307-311.

[9] Menezes CJMDS, Kirtany JK, Kamat SP. Synthesis of 7,8-methylenedioxy-4'methoxyisoflavone from Indigofera linnaei and two new related flavonoids. J. Chem. Res. 2010; 34(1): 2829.

[10] Iinuma M, Tanaka T, Matsuura S. Synthetic Studies of the Flavone Derivatives. VIII. Synthesis of Kanzakiflavones and Their Isomers. Chem. Pharm. Bull. 1984; 32(3): 1006-1010.

[11] Visweswara Rao K, Viswanadham N, A note to 7,8-dimethoxyflavone. Proc. Indian Acad. Sci., Sect. A. 1949; 29: 218-220.

[12] Parmar VS, Singh S, Jain R. Synthesis of isoflavone-H, occurring in Tephrusia maxima. Indian J. Chem., Sect. B. 1987; 26(2): 166167.
[13] Rani I. Synthesis of two naturally occurring flavonoids. Indian J. Chem., Sect. B. 1987; 26(11): 1080-1081.

[14] Otsalyuk VM, Tkachuk TM, Bondarenko SP, Chhalo VV, Khilya VP. Synthetic analogs of xanthocercin. Chem. Nat. Comp. 1998; 34(3): 284-288.

[15] Khilya VP, Tkachuk TM, Shevchuk LI. Chem. Nat. Comp. Thiazole analogs of isoflavolignans. 2000; 36(6): 574-578.

[16] Jurd L, Stevens K, Manners G. Isoflavones of the heartwood of dalbergia retusa. Phytochemistry 1972; 11(8): 2535-2540.

[17] Orlikova B, Menezes JCJMDS, Ji S, Kamat SP, Cavaleiro JAS, Diederich M. Methylenedioxy flavonoids: Assessment of cytotoxic and anti-cancer potential in human leukemia cells. Eur. J. Med. Chem. 2014; 84: 173-180.

[18] Menezes JC, Cavaleiro JA, Kamat SP, Barros CM, Domingues MR. Electrospray tandem mass spectrometry analysis of methylenedioxy chalcones, flavanones and flavones. Rapid Comm. in Mass Spectrometry. 2013; 27(12): 1303-1310.

[19] Semenov VV, Tsyganov DV, Semenova MN, Chuprov-Netochin RN, Raihstat MM, Konyushkin LD, Volynchuk PB, Marusich EI, Nazarenko VV, Leonov SV, Kiselyov AS. Efficient Synthesis of Glaziovianin A Isoflavone Series from Dill and Parsley Extracts and Their in Vitro/in Vivo Antimitotic Activity. J. Nat. Prod. 2016; 79(5): 14291438.

[20] Albert AI, Zilliken FW. Benzopyrans and use thereof in treating vascular diseases. Pat US 4814346, 1989.

[21] Poisson T, Gembus V, Dalla V, Ouder S, Levacher V. Organocatalyzed enantioselective protonation of silyl enol ethers: scope, 
limitations, and application to the preparation of enantioenriched homoisoflavones. .J. Org. Chem. 2010; 75(22): 7704-7716.

[22] Fukui K, Matsumoto T. The Synthesis of Irisolone. Bull. Chem. Soc. Japan. 1965; 38: 887-893.

[23] Kikuchi Y, Miyaichi Y, Tomimori T. Studies on Nepalese Crude Drugs. XIV. New

Flavonoids from the Root of Scutellaria prostrata JACQ. ex BENTH. Chem. Pharm. Bull. 1991; 39(6): 1466-1472.

[24] Bezuidenhout SC, Bezuidenhout BCB, Brandt EV, Ferreira D. Oligomeric isoflavonoids. Part 2. Structure and synthesis of xanthocercin $\mathrm{A}$ and $\mathrm{B}$, the first isoflavono-lignoids. J Chem. Soc. Perkin Trans. 1 1988; (5): 1237-1241.

[25] Guz NR, Stermitz FR, Johnson JB, Beeson TD, Willen S, Hsiang J, Lewis $\mathrm{K}$. Flavonolignan and flavone inhibitors of a Staphylococcus aureus multidrug resistance pump: structure-activity relationships. J. Med. Chem. 2001; 44(2): 261-268.

[26] Kurkin VA; Zapesochnaya GG. Production of flavolignins of herbacetin with the aid of peroxidase. Chem. Nat. Comp. 1990; 26(6): 710-711.

[27] Goker H, Ertan R. Studies on the synthesis of some biologically-active flavonoid derivatives. 8. Pharmazie 1990; 45(10): 734-736.

[28] Ertan R., Goker H., Ertan M, Pindur U. Synthesis of new annellated flavonoid derivatives possessing spasmolytic activity--VII. Arch. Pharm. 1989; 322(4): 237-239.

[29] Springsteel MF, Galietta LJV, Ma T, By K, Berger GO, Yang H, Dicus CW, Choung W, Quan C, Shelat AA, Guy RK, Verkman AS, Kurth MJ, Nantz MH. Benzoflavone activators of the cystic fibrosis transmembrane conductance regulator:
Towards a pharmacophore model for the nucleotidebinding domain. Bioorg. Med. Chem. 2003; 11(18): 4113-4120.

[30] Tran M, Stack GP. Antidepressant azaheterocyclylmethyl derivatives of 1,4,5-trioxaphenanthrene. Pat. US 225157 A1, 2003.

[31] Tran M, Stack GP. Antidepressant azaheterocyclylmethyl derivatives of 1,4,5-trioxaphenanthrene. Pat. US 6906206 B2, 2005.

[32] Barker G, Ellis GP, Wilson DA. Benzopyrones. Part IV. Pyrano[1,4]benzoxazinones and some dihydrobenzoxazines: synthesis, mass, and nuclear magnetic resonance spectra. J. Chem. Soc. Sect. C; 1971: 2079-2082.

[33] Raju KR, Rao PS. Chemistry of lichen products. 5. Synthesis and antimicrobial activity of some new 1,4-benzoxazinones from pulvinic acid dilactone. Indian J. Chem., Sect. B. 1986; 25: $94-96$

[34] Kumar S. Some 4H,12H-pyrano[2,3a]phenoxazin-4-ones. J. Med. Chem. 1968; 11(4): 913914.

[35] Nayak A, Jesthi PK, Rout MK. Antispasmodics and antihistaminics derived from amino and hydroxy heterocyclic compounds. J. Inst. Chem. (India) 1968; 40(3): 109-114.

[36] Bondarenko SP, Frasinyuk MS, Khilya VP. Aminomethylation of formononetin and cladrin by primary amines. Chem. Nat. Comp. 2009; 45(4): 492-495.

[37] Bondarenko SP, Frasinyuk MS, Khilya VP. Features of the aminomethylation of 7hydroxy-4'-fluoroisoflavones with primary amines. Chem. Heterocycl. Comp. 2010; 46(2) 146-150.

[38] Bondarenko SP, Frasinyuk MS, Galaev AI, Vinogradova VI. New flavonoid-containing derivatives of lupinine. Chem. Nat. Comp. 2012; 48(2): 234-237. 
[39] Garazd MM, Garazd YaL, Ogorodniichuk AS, Shilin VV, Turov AV, Khilya VP. Mannich reaction in the series of 7-hydroxe-3phenoxychromones and their derivatives. Chem. Nat. Comp. 1998; 34(5): 577-581.

[40] Gorbulenko NV, Tkachuk TM, Shokol TV, Semeniuchenko VV, Turov AV, Khilya VP. 2-[6-Alkyl-3-hetaryl-4-oxo-9,10-dihydro4H,8H-chromeno-[8,7-e][1,3]oxazin-9-yl]acetic acids Chem. Heterocycl. Comp. 2007; 43(5) 569-575.

[41] Frasinyuk MS, Bondarenko SP, Khilya VP, Liu C, Watt DS, Sviripa VM. Synthesis and Tautomerization of Hydroxylated Isoflavones Bearing Heterocyclic Hemi-Aminals. Org. Biomol. Chem. 2015; 13(4): 1053-1067.
[42] Zhong C, Yang M, Quan Z, Lin H. Chrysin derivative and preparation thereof and application thereof in treating hyperuricemia. Pat. CN $105884735,2016$.

[43] Dai J; Teng N, Peng Y, Liu Y, Cao L, Zhu J, Liu X. Biobased Benzoxazine Derived from Daidzein and Furfurylamine: Microwave-Assisted Synthesis and Thermal Properties Investigation. Chem.Sus. Chem. 2018; 11(18): 3175-3183. 